\title{
Effect of Dietary Fat, Carbohydrate, and Protein on Branched-chain Amino Acid Catabolism during Caloric Restriction
}

\author{
Jorge A. Vazquez, Emile L. Morse, and Siamak A. Adibi \\ Clinical Nutrition Unit and Department of Medicine, Montefiore Hospital and University of Pittsburgh School of Medicine, \\ Pittsburgh, Pennsylvania 15213
}

\begin{abstract}
To assess the effect of each dietary caloric source on the catabolism of branched-chain amino acids, we investigated the rate of leucine oxidation before and after obese volunteers consumed one of the following diets for one week: (a) starvation, (b) 300 or $500 \mathrm{cal}$ of fat/d, (c) 300 or $500 \mathrm{cal}$ of carbohydrate/ d, (d) 300 or $500 \mathrm{cal}$ of protein/d, (e) a mixture of carbohydrate (300 cal/d) and fat $(200 \mathrm{cal} / \mathrm{d})$, or $(f)$ a mixture of carbohydrate $(300 \mathrm{cal} / \mathrm{d})$ and protein $(200 \mathrm{cal} / \mathrm{d})$.

Starvation significantly increased the rate of leucine oxidation $(1.4 \pm 0.11$ vs. $1.8 \pm 0.16 \mathrm{mmol} / \mathrm{h}, P<0.01)$. The same occurred with the fat and protein diets. In sharp contrast, the 500 -cal carbohydrate diet significantly decreased the rate of leucine oxidation (1.3 \pm 0.13 vs. $0.6 \pm 0.09 \mathrm{mmol} / \mathrm{h}, P<0.01)$. The same occurred when a portion of the carbohydrate diet was isocalorically replaced with either fat or protein. The cumulative nitrogen excretion during the fat diet and starvation was not significantly different. As compared with the fat diets, the carbohydrate diets on the average reduced the urinary nitrogen excretion by 12 g/wk. Nitrogen balance was positive during the consumption of the 500 -cal protein diet, but negative during the consumption of carbohydrate-protein diet. The fat diets, like the protein diets and starvation, greatly increased plasma leucine $(119 \pm 13$ vs. $222 \pm 15 \mu M, P<0.01)$ and $\beta$ hydroxybutyrate $(0.12 \pm 0.02$ vs. $4.08 \pm 0.43 \mathrm{mM}, P<0.01)$ concentrations, and significantly decreased plasma glucose (96 \pm 4 vs. $66 \pm 3 \mathrm{mg} / \mathrm{dl}, P<0.01)$ and insulin $(18 \pm 4$ vs. $9 \pm 1$ $\mu \mathrm{U} / \mathrm{ml}, P<0.05)$ concentrations. These changes did not occur, or were greatly attenuated, when subjects consumed carbohydrate alone or in combination with fat or protein.

We conclude that ( $a$ ) during brief caloric restriction, dietary lipid and protein, unlike carbohydrate, do not diminish the catabolism of branched-chain amino acids and $(b)$ the decrease in branched-chain amino acid oxidation is associated with protein sparing.
\end{abstract}

\section{Introduction}

Branched-chain amino acids are major constituents of body (1) and dietary (2) proteins and comprise $46 \%$ of the dietary requirement for essential amino acids for man (3). Furthermore, they may have important roles in metabolic regulation $(4,5)$. For example, leucine may stimulate synthesis and inhibit

\footnotetext{
Address reprint requests to Dr. Siamak A. Adibi.

Received for publication 30 March 1984 and in revised form 27 March 1985.
}

J. Clin. Invest.

(c) The American Society for Clinical Investigation, Inc. 0021-9738/85/08/0737/07 \$1.00

Volume 76, August 1985, 737-743 degradation of skeletal muscle protein (6-8). Therefore, sparing branched-chain amino acids from catabolism may make a significant contribution to the promotion of protein synthesis and/or the conservation of body proteins. Indeed, there is evidence that the stimulation of branched-chain amino acid oxidation is associated with increased muscle proteolysis (9).

In the present experiments we have investigated the effects of hypocaloric amounts of carbohydrate, fat, and protein consumed individually and in combination on parameters of leucine metabolism and protein nutrition in groups of obese, female volunteers. A week of dietary caloric restriction has been used as the clinical model for testing the effects of these diets. The design of these experiments is based on the following considerations: (a) the greatest loss of body nitrogen in starvation occurs during the first week (10); (b) there is substantial evidence that starvation increases muscle oxidation of branchedchain amino acids $(11,12)$; and $(c)$ the alteration in protein metabolism in response to dietary caloric restriction appears to be similar in obese and nonobese human subjects $(10,13)$.

\section{Methods}

Experimental protocol. The studies of leucine metabolism were performed in 63 obese, female volunteers who were admitted to the Clinical Research Unit of the University of Pittsburgh School of Medicine. Each patient gave informed consent before the study. For the initial 3-4 d, subjects were given a diet that simulated their intake at home, usually exceeding $3,000 \mathrm{cal} / \mathrm{d}$. During the control period, after an overnight fast, peripheral venous blood was obtained for determination of concentrations of $\beta$-hydroxybutyrate, glucose, insulin, and amino acids, and then the rates of leucine oxidation and turnover were investigated. After the completion of these studies, the subjects were assigned to a diet containing either 0 cal, only fat $(300$ or 500 cal), only carbohydrate $(300$ or $500 \mathrm{cal})$, a mixture of carbohydrate $(300 \mathrm{cal})$ and fat $(200 \mathrm{cal})$, only protein $(300$ or $500 \mathrm{cal})$, or a mixture of carbohydrate $(300 \mathrm{cal})$ and protein $(200 \mathrm{cal})$. The sources of fat, carbohydrate, and protein were soybean oil, vegetables and fruits, and water-packed tuna, respectively. In addition, all patients received multivitamins daily. After $1 \mathrm{wk}$ of treatment with each of the above diets, the studies performed during the control period were repeated. In addition, all urine and stool excreted during the week of treatment was collected and pooled for nitrogen analysis. The mean age, height, and body weight of all groups were comparable (Table I); statistically there was no significant difference in regard to any of these characteristics. Furthermore, there was no significant difference in the rates of leucine oxidation and turnover and plasma concentrations of $\beta$ hydroxybutyrate, glucose, insulin, and amino acids among the groups before dietary treatments (see Tables III-V).

The rates of valine oxidation and turnover during the control period and after $1 \mathrm{wk}$ of starvation were determined in an additional group of five obese subjects. The group was comparable to the group used for the investigation of the effect of starvation on parameters of leucine metabolism.

Parameters of leucine metabolism. The rates of turnover and oxidation of $\left[{ }^{14} \mathrm{C}\right]$ leucine were investigated by a technique requiring 
Table I. Characteristics of Groups

\begin{tabular}{|c|c|c|c|c|}
\hline Dietary treatment & $\begin{array}{l}\text { No. of } \\
\text { subjects }\end{array}$ & Age & Height & Weight \\
\hline & & $y r$ & $\mathrm{~cm}$ & kg \\
\hline Starvation & 7 & $37.9 \pm 4.8$ & $164.0 \pm 1.3$ & $105.8 \pm 5.5$ \\
\hline \multicolumn{5}{|l|}{ Fat diet } \\
\hline $300 \mathrm{cal}$ & 7 & $32.6 \pm 3.1$ & $163.5 \pm 2.8$ & $113.5 \pm 13.2$ \\
\hline $500 \mathrm{cal}$ & 7 & $39.1 \pm 4.3$ & $160.7 \pm 2.7$ & $122.9 \pm 7.3$ \\
\hline \multicolumn{5}{|l|}{ Carbohydrate diet } \\
\hline $300 \mathrm{cal}$ & 4 & $34.9 \pm 3.0$ & $159.5 \pm 2.3$ & $124.0 \pm 15.2$ \\
\hline $500 \mathrm{cal}$ & 7 & $35.0 \pm 3.3$ & $160.9 \pm 2.5$ & $117.7 \pm 11.8$ \\
\hline \multicolumn{5}{|l|}{ Protein diet } \\
\hline $300 \mathrm{cal}$ & 8 & $37.6 \pm 5.0$ & $163.9 \pm 4.7$ & $134.9 \pm 17.4$ \\
\hline $500 \mathrm{cal}$ & 6 & $38.3 \pm 3.3$ & $171.4 \pm 2.6$ & $139.5 \pm 14.9$ \\
\hline Carbohydrate-fat diet & 6 & $33.0 \pm 1.7$ & $159.0 \pm 1.6$ & $127.8 \pm 13.1$ \\
\hline Carbohydrate-protein diet & 6 & $33.4 \pm 3.0$ & $164.8 \pm 3.5$ & $138.6 \pm 20.9$ \\
\hline
\end{tabular}

All subjects were women. The data are presented as means \pm SEM.

intravenous infusion of a trace amount of this amino acid at a constant rate. Details of this technique have been previously published (14). In brief, after an overnight fast, a bolus dose of $5 \mu \mathrm{Ci}$ of $\left[1-{ }^{14} \mathrm{C}\right]$ leucine (Amersham Corp., Arlington Heights, IL; $58 \mathrm{mCi} / \mathrm{mmol}$ ) was administered through an indwelling catheter into a peripheral vein. Immediately after this priming dose, a continuous infusion of leucine was begun. $\left[1-{ }^{14} \mathrm{C}\right]$ leucine dissolved in physiologic saline was delivered over a period of $3 \mathrm{~h}$ at a constant rate of $0.21 \mathrm{ml} / \mathrm{min}(0.045 \mu \mathrm{Ci} / \mathrm{min})$. For determination of specific activity of $\mathrm{CO}_{2}$ in breath, the patients blew through a tube into scintillation counting vials containing a $\mathrm{CO}_{2}-$ trapping mixture. The $\mathrm{CO}_{2}$-trapping mixture consisted of $4 \mathrm{ml}$ of hydroxide of hyamine-10X (Rohm \& Haas Co., Philadelphia, PA), absolute ethanol $(1: 1, \mathrm{vol} / \mathrm{vol})$, and thymolphthalein indicator. The solution was calibrated to change color from blue to clear when 2 $\mathrm{mmol}$ of $\mathrm{CO}_{2}$ had been collected. After addition of $10 \mathrm{ml}$ of Liquifluortoluene scintillation counting fluid (New England Nuclear, Boston, MA), samples were assayed for radioactivity in a scintillation counter.

Peripheral venous blood and expired air were collected at 135 , 150,165 , and 180 min after the start of the infusion. Previous studies in fed and starved obese subjects showed that the specific activities of leucine in plasma and $\mathrm{CO}_{2}$ in expired air had reached near-constant values at these time intervals (14). The fact that the specific activity of leucine in plasma and $\mathrm{CO}_{2}$ in expired air had reached plateau in each subject of the present experiment was confirmed by close agreement among the four values; coefficient of variation was $5 \%$ or less of the mean specific activity.

The rate of $\mathrm{CO}_{2}$ production was measured in each experiment utilizing an automatic system that allows breath-to-breath measurement of expired air volume and $\mathrm{CO}_{2}$ concentration (Beckman Metabolic Measurement Cart, Sensormedics, Anaheim, CA). To assure complete collection of expired air, patients were furnished with a rubber mouthpiece and a nose clip. The accuracy of expired air volume and $\mathrm{CO}_{2}$ concentration measurement with this system is $\pm 2 \%$ and $\pm 0.1 \%$, respectively.

Rates of turnover and oxidation of leucine were calculated by the following formulas: $Q=I / S A_{\mathrm{pl}}$, where $Q=$ turnover rate (millimoles per hour), $I=$ infusion rate of tracer (disintegrations per minute/hour), and $S A_{\mathrm{pl}}=$ plasma specific activity of tracer during steady state (disintegrations per minute/millimole); $O x=\left(S A_{\mathrm{b}} \times \mathrm{PR}\right) /\left(S A_{\mathrm{pl}} \times \mathrm{FR}\right)$, where $O x=$ oxidation rate (millimoles per hour), $S A_{b}=$ specific activity of $\mathrm{CO}_{2}$ in expired air at steady state, $P R=\mathrm{CO}_{2}$ production rate (millimoles per hour), $S A_{\mathrm{pt}}=$ plasma specific activity of tracer at steady state (disintegrations per minute/millimole), and $F R=$ fraction of $\mathrm{CO}_{2}$ recovered during infusion of $\left[{ }^{14} \mathrm{C}\right]$ bicarbonate.
In calculating the above rates the following three factors were considered:

(a) Specific activity. The plasma specific activity of ketoisocaproate (KIC) ${ }^{1}$ instead of leucine has been suggested for calculating the rate of oxidation of leucine (15). However, there is no evidence that specific activity of KIC in plasma has any relevance to the specific activity of $\mathrm{KIC}$ in tissues. In contrast, we and others have found that during a constant infusion when the specific activity of leucine reaches a constant value in plasma, it also reaches a constant value in tissue intracellular compartment $(16,17)$. Furthermore, at plateau, intracellular specific activities closely approximate the specific activity of leucine in plasma in both the fed and starved state. A previous study (15) has shown that during infusion of $\left[{ }^{13} \mathrm{C}\right]$ leucine over a wide range of dietary intake the ratio of KIC to leucine specific activity in plasma remains constant at $\sim 0.77$. Therefore, using specific activity of KIC instead of leucine would not alter the findings of the present experiment. It would similarly increase rates of leucine oxidation before and after each dietary treatment.

(b) Weight. For the following reasons the rates of leucine oxidation and turnover are not expressed per kilogram of body weight: each subject served as her own control; the amount of weight loss during each treatment when compared with the initial body weight was rather small; and there was uncertainty as to the proportion of the decrease in body weight which was due to body fluid and tissue.

(c) ${ }^{14} \mathrm{CO}_{2}$ recovery. To assess the effect of starvation on the recovery of ${ }^{14} \mathrm{CO}_{2}$, we investigated the rate of ${ }^{14} \mathrm{CO}_{2}$ production in expired air during a primed continuous infusion of $\mathrm{NaH}^{14} \mathrm{CO}_{3}$. The rate of ${ }^{14} \mathrm{CO}_{2}$ production was investigated before and after $1 \mathrm{wk}$ of starvation in three obese volunteers. The infusion solution was prepared by adding $\mathrm{NaH}^{14} \mathrm{CO}_{3}$ to $8.4 \% \mathrm{NaHCO}_{3}$ solution (pH 7.0-8.5). The subjects received a priming dose of $3 \mu \mathrm{Ci}$ over 1 min before undergoing a continuous infusion with the bicarbonate solution at a rate of 0.15 $\mathrm{ml} / \mathrm{min}(0.045 \mu \mathrm{Ci} / \mathrm{min})$. The period of continuous infusion was $3 \mathrm{~h}$. The breath samples for determination of $\mathrm{CO}_{2}$ specific activity were collected at 135, 150,165, and $180 \mathrm{~min}$ after the start of infusion. The specific activity of $\mathrm{CO}_{2}$ in expired air rose immediately and reached steady state by $120 \mathrm{~min}$. The rate of ${ }^{14} \mathrm{CO}_{2}$ recovery during the infusion of $\left[{ }^{14} \mathrm{C}\right]$ bicarbonate was calculated by the following formula: $R=\left(S A_{\mathrm{b}} \times P R \times 100\right) / I$, where $R=$ percent recovery of ${ }^{14} \mathrm{CO}_{2}$, and others are as defined above.

The mean specific activity of $\mathrm{CO}_{2}$ in the expired air, $\mathrm{CO}_{2}$ production rate, and $\% \mathrm{CO}_{2}$ recovery before and after starvation are shown in Table II. The recovery of ${ }^{14} \mathrm{CO}_{2}$ in expired air was $60 \%$ in the control period and remained the same after 1 wk of starvation. Although we did not investigate ${ }^{14} \mathrm{CO}_{2}$ recovery after each hypocaloric diet, it is unlikely that partial starvation would alter ${ }^{14} \mathrm{CO}_{2}$ recovery in that total starvation, the most severe caloric treatment in our experiment, was without effect. We, therefore, corrected all rates of leucine oxidation by the same ${ }^{14} \mathrm{CO}_{2}$ recovery factor $(60 \%)$.

Parameters of valine metabolism. The rates of $\left[{ }^{14} \mathrm{C}\right]$ valine oxidation and turnover were investigated by the same methods used to study parameters of leucine metabolism. The only difference was the substitution of $\left[1{ }^{14} \mathrm{C}\right]$ valine (Amersham Corp., $57 \mathrm{mCi} / \mathrm{mmol}$ ) for [1${ }^{14}$ C]leucine.

Methods of analysis. Plasma concentrations of $\beta$-hydroxybutyrate, amino acids, glucose, and insulin were determined by enzymatic (18), ion-exchange chromatography (13), hexokinase, and radioimmunoassay (Cambridge Nuclear Radiopharmaceutical Corp., Billerica, MA) methods, respectively. Total nitrogen in the urine and feces was determined by a micro-Kjeldahl technique.

The concentrations of radioactively labeled valine and leucine were determined by modification of the method of Hutson et al. (19). Briefly, $4 \mathrm{ml}$ of a $6 \%$ sulfosalicylic acid extract $(3: 1$, vol/vol) was

1. Abbreviations used in this paper: BCKA, branched-chain $\alpha$-ketoacid; KIC, ketoisocaproate. 
Table II. Effect of Diet on ${ }^{14} \mathrm{CO}_{2}$ Recovery

\begin{tabular}{llll}
\hline Starvation & $\begin{array}{l}\mathrm{CO}_{2} \\
\text { specific activity }\end{array}$ & $\begin{array}{l}\mathrm{CO}_{2} \\
\text { production rate }\end{array}$ & $\begin{array}{l}\mathrm{CO}_{2} \\
\text { recovery }\end{array}$ \\
\hline & $d p m / m m o l$ & mmol/min & $\%$ infused \\
Before & $7,068 \pm 300$ & $8.23 \pm 0.12$ & $60 \pm 3$ \\
After & $8,171 \pm 393$ & $7.02 \pm 0.63$ & $60 \pm 2$ \\
\hline
\end{tabular}

The data are presented as means \pm SEM in three subjects.

applied to a $4 \times 0.9-\mathrm{cm}$ column of Dowex $50 \mathrm{~W}-\times 8$ cation exchange resin (Dow Chemical Co., Indianapolis, IN). The column was eluted with $10 \mathrm{ml} 0.01 \mathrm{~N} \mathrm{HCl}$ to remove ketoacids. Subsequently, amino acids were eluted with $6 \mathrm{ml}$ of $4 \mathrm{~N} \mathrm{NH}_{4} \mathrm{OH}$; the sample was evaporated to dryness. The residue was dissolved in $10 \mathrm{ml}$ of Liquifluor scintillation cocktail and was assayed for radioactivity in a Packard Tricarb scintillation counter (Packard Instrument Co., Downers Grove, IL).

Statistics. Data from the same and different groups were evaluated statistically by the paired $t$ test and analysis of variance, respectively (20). The relationship of oxidation rate and leucine, $\beta$-hydroxybutyrate, glucose and insulin concentrations was evaluated by the correlation coefficient (20). Two-tailed tests were used in all cases. All data are presented as mean \pm standard error of the mean.

\section{Results}

Parameters of branched-chain amino acid metabolism. The rates of leucine oxidation of each subject before and after 1 wk of starvation and consumption of diets that consisted of $500 \mathrm{cal}$ of fat, carbohydrate, or protein are detailed in Fig. 1. The mean \pm standard error of the mean of these rates are shown in Table III. The rate of leucine oxidation increased in each subject receiving the starvation, fat, and protein diets and decreased in each subject consuming the carbohydrate diet. These changes were all statistically significant (Table III). The average increase in the rate of leucine oxidation during consumption of the 500 -cal fat diet was $57 \%$ and the average decrease during consumption of the 500-cal carbohydrate diet was $38 \%$.

To assess the quantitative importance of these diets, we investigated the effect of consuming diets consisting of $300 \mathrm{cal}$

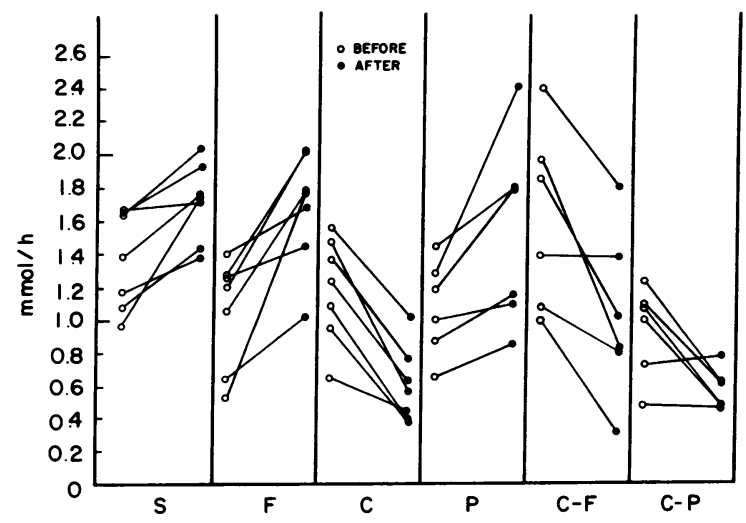

Figure 1. The rates of leucine oxidation before and after each subject received the starvation (S), 500-cal fat (F), 500-cal carbohydrate (C), 500 -cal protein (P), 300-cal carbohydrate and 200-cal fat (C-F), and 300 -cal carbohydrate and 200-cal protein (C-P) diets. The statistical analysis of data is shown in Table III.
Table III. Parameters of Leucine Metabolism

\begin{tabular}{|c|c|c|}
\hline Dietary treatment & Oxidation rate & Turnover rat \\
\hline & $\mathrm{mmol} / \mathrm{h}$ & $\mathrm{mmol} / \mathrm{h}$ \\
\hline \multicolumn{3}{|l|}{ Starvation } \\
\hline Before & $1.4 \pm 0.11$ & $8.3 \pm 0.5$ \\
\hline After & $1.8 \pm 0.16 \S$ & $6.4 \pm 0.4 \ddagger$ \\
\hline
\end{tabular}

Fat diet

$300 \mathrm{cal}$

Before

$1.6 \pm 0.22$

$9.9 \pm 0.8$

After

$2.0 \pm 0.24 \ddagger$

$6.8 \pm 0.7 \S$

$500 \mathrm{cal}$

Before

$1.1 \pm 0.14$

$10.0 \pm 0.9$

After

$1.8 \pm 0.14 \S$

$7.3 \pm 0.7^{*}$

Carbohydrate diet

$300 \mathrm{cal}$

Before

$1.6 \pm 0.14$

$8.6 \pm 0.5$

After

$1.1 \pm 0.22$

$7.4 \pm 0.6 *$

$500 \mathrm{cal}$

Before

$1.3 \pm 0.13$

$9.2 \pm 0.8$

After

$0.6 \pm 0.09 \S$

$6.8 \pm 0.4 \S$

Protein diet

$300 \mathrm{cal}$

Before

After

$500 \mathrm{cal}$

Before

$1.2 \pm 0.12$

$7.8 \pm 0.8$

$1.5 \pm 0.20$ *

$6.7 \pm 0.6$

After

$1.1 \pm 0.12$

$8.3 \pm 0.6$

$1.6 \pm 0.25^{*}$

$7.3 \pm 0.6$

Carbohydrate-fat diet

$\begin{array}{lll}\text { Before } & 1.7 \pm 0.24 & 7.9 \pm 0.8 \\ \text { After } & 1.1 \pm 0.22 \ddagger & 5.7 \pm 0.7 \ddagger\end{array}$

Carbohydrate-protein diet

Before

$1.0 \pm 0.12$

$8.8 \pm 0.6$

After

$0.6 \pm 0.05$ *

$7.5 \pm 0.8$

Values given as means \pm SEM.

$*$, $\ddagger$, $P$ values $<0.05,0.02$, and 0.01 , respectively, as evaluated by the paired $t$ test. Duration of treatment with each diet was 1 week.

of fat, carbohydrate, or protein. These data are summarized in Table III. The increase in leucine oxidation with the 300cal protein diet was similar to increases with 500-cal diets (29 vs. $29 \%$ ), and the decrease in the rate of leucine oxidation with the 300-cal carbohydrate diet was similar to the decrease by the 500 -cal diet ( 40 vs. $38 \%$ ). On the other hand, the increase in leucine oxidation was greater with the 500-cal than with the 300-cal fat diet (57 vs. $20 \%$ ).

We then investigated whether dietary carbohydrate would reduce the oxidation of leucine if fat or protein were added to the diet. The rate of leucine oxidation was determined before and 1 wk after subjects consumed a diet containing $300 \mathrm{cal}$ as carbohydrate and $200 \mathrm{cal}$ of fat or protein. Except for one subject, consumption of the carbohydrate-fat and carbohydrate-protein diet resulted in a decrease in the rate of leucine oxidation (Fig. 1). These decreases were statistically significant (Table III).

The rates of leucine turnover of each subject before and after 1 wk of starvation and the 500-cal hypocaloric diets are 
detailed in Fig. 2. The mean \pm standard error of the mean of these rates as well as those before and after the 300 -cal hypocaloric diets are summarized in Table III. All dietary treatments reduced the rate of leucine turnover. However, changes with the protein-containing diets were not significant, while reductions with the other diets were (Table III). The magnitudes of reduction in leucine turnover rate with starvation (23\%), the 500 -cal fat diet (27\%), and the 500-cal carbohydrate diet $(26 \%)$ were approximately similar.

To investigate whether metabolism of other branchedchain amino acids is similarly affected by dietary caloric restriction, we determined the rates (millimoles per hour) of valine oxidation and turnover in five subjects before and after 1 wk of starvation. Starvation significantly increased the rate of oxidation $(0.77 \pm 0.3$ vs. $1.00 \pm 0.19$ [mean \pm SEM], $P<0.05)$ and significantly reduced the rate of turnover $(6.12 \pm 0.85$ vs. $5.37 \pm 0.83, P<0.02$ ).

Parameters of protein nutrition. The cumulative urinary excretion of nitrogen during each diet is shown in Table IV. Statistical analysis of the data showed that nitrogen excretion during the 300- and 500-cal carbohydrate and the carbohydratefat diets were all significantly smaller than the nitrogen excretion during starvation and the 300- and 500-cal fat diets. Furthermore, there was no significant difference between nitrogen excretion during starvation and the fat diets. Although nitrogen excretion was smaller during the 500-cal than during 300-cal carbohydrate diet, the difference was not statistically significant. As compared with the fat diets, the carbohydrate diets on the average reduced the urinary nitrogen excretion by $12 \mathrm{~g} / \mathrm{wk}$.

As might be expected, nitrogen excretion during consumption of the protein-containing diets was considerably greater than when protein was not included in the diet (Table IV). Therefore, to account for the dietary intake we calculated the cumulative nitrogen balance [(dietary intake) - (urinary and fecal losses)] when the diet contained protein. The data showed that nitrogen balance was near neutral when subjects consumed the 300-cal protein diet, positive during the 500-cal protein diet, but negative during the carbohydrate-protein diet. Among

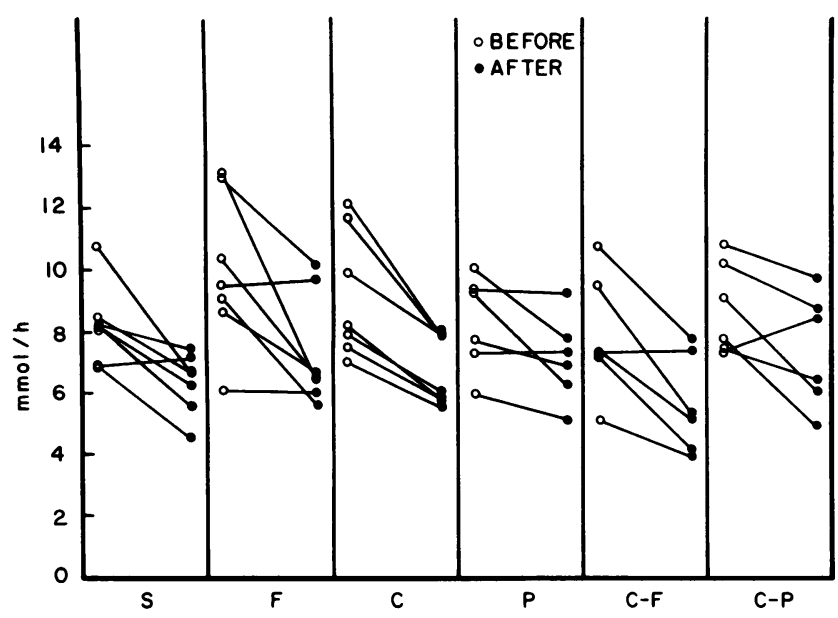

Figure 2. The rates of leucine turnover before and after each subject received the starvation (S), 500-cal fat (F), 500-cal carbohydrate (C), 500-cal protein (P), 300-cal carbohydrate and 200-cal fat (C-F), and $300-\mathrm{cal}$ carbohydrate and 200-cal protein (C-P) diets. The statistical analysis of the data is shown in Table III.
Table IV. Cumulative Nitrogen Excretion and Balance

\begin{tabular}{lccl}
\hline Dietary treatment & $\begin{array}{l}\text { Nitrogen } \\
\text { intake }\end{array}$ & $\begin{array}{l}\text { Urinary } \\
\text { excretion }\end{array}$ & $\begin{array}{l}\text { Nitrogen } \\
\text { balance }\end{array}$ \\
\hline & $g N / w k$ & $g N / w k$ & $g N / w k$ \\
Starvation & 0 & $58.5 \pm 3.7$ & $-61.4 \pm 3.7$ \\
$\begin{array}{l}\text { Fat diet } \\
300 \text { cal }\end{array}$ & 0 & $58.1 \pm 3.3$ & $-61.1 \pm 3.3$ \\
500 cal & 0 & $52.4 \pm 3.2$ & $-55.4 \pm 3.2$ \\
$\begin{array}{l}\text { Carbohydrate diet } \\
300 \text { cal }\end{array}$ & 0 & & \\
500 cal & 0 & $46.6 \pm 2.7^{*}$ & $-49.5 \pm 2.7^{*}$ \\
$\begin{array}{l}\text { Carbohydrate-fat diet } \\
\text { Protein diet }\end{array} \quad 0$ & $46.3 \pm 2.9^{*}$ & $-43.2 \pm 2.9^{*}$ \\
$\quad \begin{array}{l}300 \text { cal } \\
500 \text { cal }\end{array}$ & 76.8 & $75.0 \pm 5.0^{*}$ & $-49.6 \pm 2.0^{*}$ \\
$\quad \begin{array}{l}\text { Carbohydrate-protein } \\
\text { diet }\end{array}$ & 128.1 & $118.1 \pm 9.9 \S$ & $-1.1 \pm 5.4 \S$ \\
& 51.0 & $72.8 \pm 4.0^{*}$ & $-24.7 \pm 4.0 \S$ \\
\hline
\end{tabular}

Values given as means \pm SEM.

*, $\S P$ values $<0.05,0.01$, respectively, as compared to values on the starvation diet.

the nonprotein-containing diets, the cumulative nitrogen balance was least negative with the 500-cal carbohydrate diet.

As in previous studies with brief starvation $(13,21,22)$, the changes in plasma aminogram with all diets were confined to branched-chain amino acids and alanine. Therefore, only the concentrations of alanine and leucine (representative branched-chain amino acid) are shown in Table V. There was a near-twofold increase in plasma leucine concentration with starvation and 300- and 500-cal fat and protein diets. In contrast, consumption of the 300 -cal carbohydrate diet resulted in a modest increase in plasma leucine concentration. When the daily carbohydrate intake was increased to $500 \mathrm{cal}$, there was no significant change in leucine concentration. This inhibitory effect on plasma branched-chain amino acid concentration persisted even when fat or protein was combined with carbohydrate. Unlike plasma leucine concentration, plasma alanine concentration was significantly reduced by all diets except the carbohydrate-protein diet.

Metabolic profile. In view of previously reported effects of ketone bodies, glucose and insulin on branched-chain amino acid oxidation (12), we also investigated plasma concentrations of these substrates and hormone before and after starvation and each of the hypocaloric diets (Table VI). The plasma concentration of $\beta$-hydroxybutyrate was increased over 40 -fold by starvation and the fat diets, and nearly 20 -fold by the protein diets. In comparison, there were far smaller increases in the plasma concentration of $\beta$-hydroxybutyrate with the carbohydrate diets. This inhibitory effect on plasma ketone body concentration persisted even when fat or protein was mixed with carbohydrate.

The fat, carbohydrate, and protein diets, like starvation, significantly reduced the plasma glucose concentration. However, the decrease in plasma glucose concentration was greater during the 500 -cal fat diet $(31 \%)$ than during the 500 -cal carbohydrate $(16 \%)$ or protein $(17 \%)$ diet. The decrease in plasma glucose concentration with the carbohydrate-fat and carbohydrate-protein diets was not statistically significant. 
Table V. Plasma Amino Acid Concentrations

\begin{tabular}{|c|c|c|}
\hline Dietary treatment & Leucine & Alanine \\
\hline & $\mu M$ & $\mu M$ \\
\hline \multicolumn{3}{|l|}{ Starvation } \\
\hline Before & $127 \pm 9$ & $296 \pm 42$ \\
\hline After & $209 \pm 12 \S$ & $189 \pm 14^{*}$ \\
\hline \multicolumn{3}{|l|}{ Fat diet } \\
\hline \multicolumn{3}{|l|}{$300 \mathrm{cal}$} \\
\hline Before & $122 \pm 13$ & $357 \pm 42$ \\
\hline After & $240 \pm 15 \S$ & $199 \pm 16^{*}$ \\
\hline \multicolumn{3}{|l|}{$500 \mathrm{cal}$} \\
\hline Before & $119 \pm 13$ & $312 \pm 38$ \\
\hline After & $222 \pm 15 \S$ & $204 \pm 12 \ddagger$ \\
\hline \multicolumn{3}{|l|}{ Carbohydrate diet } \\
\hline \multicolumn{3}{|c|}{$300 \mathrm{cal}$} \\
\hline Before & $111 \pm 6$ & $308 \pm 24$ \\
\hline After & $148 \pm 9 \S$ & $195 \pm 17 \S$ \\
\hline \multicolumn{3}{|l|}{$500 \mathrm{cal}$} \\
\hline Before & $144 \pm 7$ & $365 \pm 26$ \\
\hline After & $131 \pm 8$ & $257 \pm 18 \S$ \\
\hline \multicolumn{3}{|l|}{ Protein diet } \\
\hline \multicolumn{3}{|l|}{$300 \mathrm{cal}$} \\
\hline Before & $121 \pm 8$ & $372 \pm 21$ \\
\hline After & $223 \pm 8 \S$ & $251 \pm 23 \S$ \\
\hline \multicolumn{3}{|l|}{$500 \mathrm{cal}$} \\
\hline Before & $111 \pm 9$ & $384 \pm 26$ \\
\hline After & $196 \pm 14 \S$ & $246 \pm 10 \S$ \\
\hline \multicolumn{3}{|c|}{ Carbohydrate-fat diet } \\
\hline Before & $150 \pm 10$ & $365 \pm 26$ \\
\hline After & $153 \pm 19$ & $285 \pm 25 \S$ \\
\hline \multicolumn{3}{|c|}{ Carbohydrate-protein diet } \\
\hline Before & $118 \pm 7$ & $363 \pm 22$ \\
\hline After & $125 \pm 11$ & $315 \pm 47$ \\
\hline
\end{tabular}

Values are given as means \pm SEM.

$*$, $\ddagger$ $\S P$ values $<0.05,0.02$, and 0.01 , respectively, as evaluated by the paired $t$ test. Duration of treatment with each diet was 1 wk.

The fat and protein diets, like starvation, significantly reduced plasma insulin level. The decrease in insulin level was more pronounced during the fat than protein diets $(53-50 \%$ vs. $35-39 \%$ ). The plasma insulin level also fell when the 300 cal carbohydrate diet was consumed, but remained unchanged when carbohydrate intake was increased to 500 cal per day. The decrease in insulin level was statistically significant with the carbohydrate-protein diet, but not with the carbohydratefat diet.

It is pertinent to mention that, although we have presented data on plasma concentrations of amino acids, fuels, and insulin on the 7th $d$ of treatment, essentially the same results were obtained from analysis of plasma obtained on earlier days.

Statistical correlations. Statistical correlations between changes in the rate of leucine oxidation and changes in plasma concentrations of leucine, $\beta$-hydroxybutyrate, glucose, and insulin are shown in Fig. 3. The relation was direct as far as changes in plasma concentration of leucine $(r=0.937, P$

Table VI. Plasma Ketone Body, Glucose, and Insulin Concentrations

\begin{tabular}{llll}
\hline Dietary treatment & $\beta$-Hydroxybutyrate & Glucose & Insulin \\
\hline & $m M$ & $m g / d l$ & $\mu U / m l$ \\
Starvation & & & \\
Before & $0.09 \pm 0.02$ & $97 \pm 3$ & $19 \pm 3$ \\
After & $3.46 \pm 0.25 \S$ & $73 \pm 4 \S$ & $10 \pm 1 \ddagger$
\end{tabular}

Fat diet

$300 \mathrm{cal}$

Before

After

$500 \mathrm{cal}$

Before

After

Carbohydrate diet

$300 \mathrm{cal}$

Before

After

$500 \mathrm{cal}$

Before

After

$\begin{array}{lcc}0.08 \pm 0.02 & 87 \pm 4 & 15 \pm 3 \\ 3.19 \pm 0.15 \S & 60 \pm 3 \S & 7 \pm 1 \S \\ & & \\ 0.12 \pm 0.02 & 96 \pm 4 & 18 \pm 4 \\ 4.08 \pm 0.43 \S & 66 \pm 3 \S & 9 \pm 1^{*}\end{array}$

Protein diet

$300 \mathrm{cal}$

Before

After

$500 \mathrm{cal}$

Before

After

Carbohydrate-fat diet

Before
After

Carbohydrate-protein diet

Before

After

$0.56 \pm 0.07 \S$

$0.10 \pm 0.01$
$2.06 \pm 0.25 \S$
$0.09 \pm 0.01$
$1.48 \pm 0.36 \S$

$0.13 \pm 0.07$
$0.87 \pm 0.17 \S$
$0.09 \pm 0.02$
$0.56 \pm 0.07 \S$

$87 \pm 3 \quad 23 \pm 3$

$59 \pm 3 \S \quad 15 \pm 2 \S$

$97 \pm 4 \quad 23 \pm 2$

$80 \pm 3 \S \quad 14 \pm 2 \S$

Values are given as means \pm SEM.

*, $\ddagger$, $₹ P$ values of $<0.05,0.02$, and 0.01 , respectively, as evaluated by the paired $t$ test. Duration of treatment with each diet was $1 \mathrm{wk}$.

$<0.001)$ and $\beta$-hydroxybutyrate $(r=0.866, P<0.001)$ were concerned, but inverse with respect to plasma concentrations of glucose $(r=-0.787, P<0.001)$ and insulin $(r=-0.754$, $P<0.001)$.

\section{Discussion}

The results of the present experiments show that there is a sharp contrast between the effect of carbohydrate and that of fat and protein on branched-chain amino acid oxidation during brief caloric restriction. The rate of leucine oxidation was significantly reduced in subjects receiving the 300 - and 500-cal carbohydrate diets, whereas there was a significant increase in oxidation rate when subjects consumed the same amount of calories in the form of fat or protein. In view of the fact that the same enzyme complex is responsible for committing all three branched-chain amino acids to oxidative degradation (11) and starvation similarly affected metabolism 

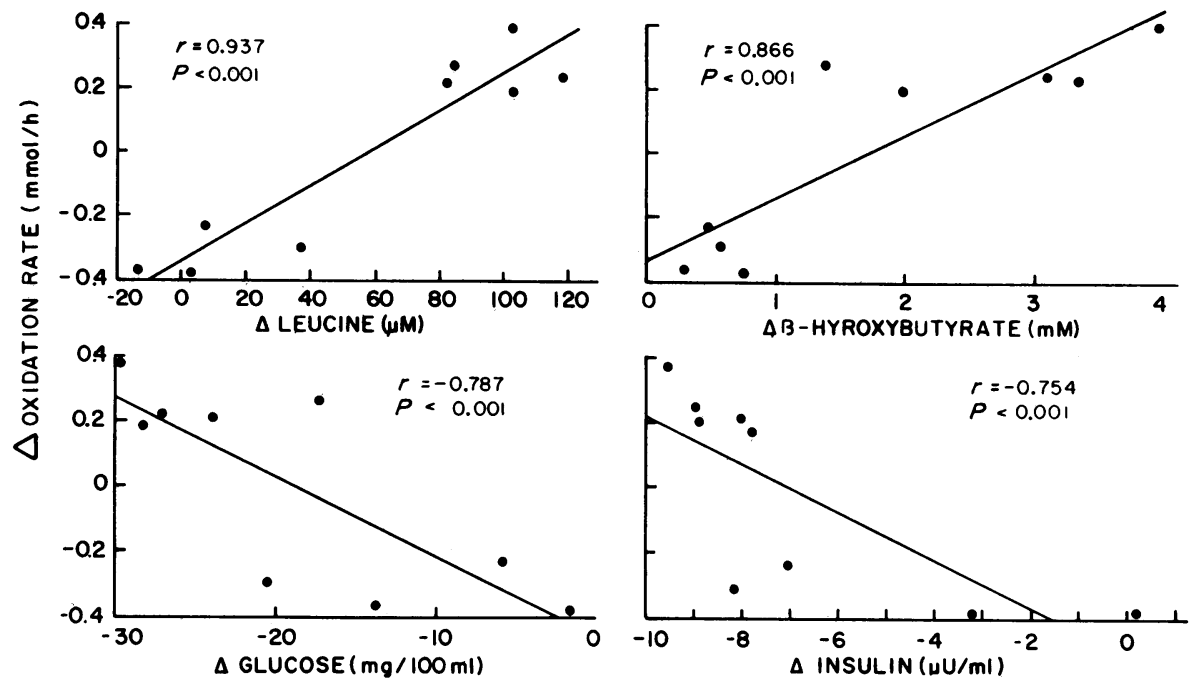

Figure 3. Statistical correlation between changes in the rate of leucine oxidation and changes in plasma concentration of either leucine, $\beta$-hydroxybutyrate, glucose, or insulin. of leucine and valine, we considered it unnecessary to investigate the effects of various hypocaloric diets on oxidation of either valine or isoleucine.

Although the biochemical mechanism of alteration in leucine catabolism was not investigated, the data suggest that the different effects of carbohydrate versus fat and protein on leucine oxidation may possibly be related to their varied effects on protein metabolism. For example, plasma leucine concentration was greatly increased during the consumption of the 500-cal fat and protein diet whereas it was not significantly affected with the 500-cal carbohydrate diet (Table V). A consistent finding of the present experiment was that, whenever there was a large (65\% or higher) increase in plasma leucine concentration, there was invariably a significant increase in the rate of leucine oxidation. In fact, statistically there was a direct relationship between changes in oxidation rates and changes in plasma concentration of leucine (Fig. 3).

The rate of leucine oxidation was studied as the rate of $\alpha$ decarboxylation of this amino acid. This reaction is catalyzed by branched-chain $\alpha$-ketoacid (BCKA) dehydrogenase, which normally exists in inactive (phosphorylated) and active (dephosphorylated) forms. Previous studies in rats have shown that caloric deficiency, caused by dietary deprivation (starvation) or impaired utilization (diabetes), results in a greater conversion of BCKA dehydrogenase from inactive to active form, accounting for the increased branched-chain amino acid oxidation by rat tissues in these conditions (23). It appears well established that leucine activates BCKA dehydrogenase (12). For example, oral administration of leucine in rats is followed by prompt activation of BCKA dehydrogenase and enhancement of valine oxidation (24). The mechanism of enzyme activation appears to be inhibition of phosphorylation of BCKA dehydrogenase by leucine $(25,26)$.

Undoubtedly, other factors (12) besides leucine are involved in regulation of branched-chain amino acid oxidation. This is suggested by the decrease in leucine oxidation despite near normal plasma leucine concentration during consumption of the carbohydrate diet. Furthermore, statistically there was a direct relationship between changes in oxidation rates and changes in plasma ketone body concentration and an inverse relationship between changes in oxidation rates and changes in plasma concentration of either glucose or insulin (Fig. 3).
There is evidence that in the skeletal muscle, the principal site for branched-chain amino acid catabolism (11), ketone bodies stimulate, and glucose and insulin inhibit, leucine oxidation $(19,27,28)$. Therefore, it appears that changes in plasma concentrations of leucine, ketone bodies, glucose, and insulin are all associated with alterations in leucine oxidation. From in vivo studies, such as the present experiment, it is difficult to ascertain whether the effect is a direct or indirect one and to assign quantitative importance to each factor.

In contrast to the rate of oxidation, the rate of leucine turnover was similarly affected by the fat and carbohydrate diets. In other words, neither diet prevented the decrease in leucine turnover that occurs during caloric restriction. The rate of turnover is a measure of the amount of leucine that moves in and out of plasma per unit time. The rate of inflow is determined by the rate of body protein breakdown and the rate of outflow is determined by the rates of protein incorporation and oxidation of leucine. Under the condition of a plateau in the specific activity of leucine in plasma, such as in the present experiments, the rates of inflow and outflow become equal and are represented by the rate of turnover. Therefore, knowing the rates of turnover and oxidation, the rates of synthesis and breakdown of body proteins can be calculated. However, due to uncertainty regarding the extent of recycling of leucine within tissue proteins, the calculation of rates of protein synthesis and breakdown may not be entirely valid. Nevertheless, it seems reasonable to speculate that the change in plasma leucine turnover reflects a change in tissue protein turnover. If this speculation is valid, the data then indicate that maintenance of tissue protein turnover during caloric restriction is more dependent on dietary protein than either carbohydrate or fat.

In conclusion, our data show that dietary carbohydrate spares body protein during brief caloric restriction whereas dietary fat has no such effect. This observation is supported by the differences in nitrogen excretion, leucine oxidation, and plasma aminogram. Based on these parameters, protein sparing is near maximum when the daily intake of carbohydrate is as little as $300 \mathrm{cal}$ per day, because increasing the intake to $\mathbf{5 0 0}$ cal per day only modestly increased the protein sparing effect. Although subjects receiving the 500-cal protein diet were in positive nitrogen balance, they had alterations in plasma 
aminogram and branched-chain amino acid oxidation, which were similar to those in subjects receiving no calories. A discrepancy between parameters of protein nutrition was also observed in subjects receiving the carbohydrate-protein diet. These subjects had a negative nitrogen balance even though their catabolism of branched-chain amino acids was reduced and their plasma aminogram was maintained near normal. Finally, the present data may have application in the design of hypocaloric diets for treating obesity. The data show that substitution of a portion of carbohydrate calories by either fat or protein does not compromise the effect of carbohydrate on conservation of body proteins and branched-chain amino acids, respectively.

\section{Acknowledgments}

We are indebted to the nurses and dieticians of the Clinical Research Unit of the Presbyterian-University Hospital for the performance of these studies. We thank Mr. George A. Paleos and Ms. Germaine Branthoover for their technical assistance.

This work was supported by National Institutes of Health grants AM-15855 and RR-00056. Dr. Vazquez was supported by a Postdoctoral Fellowship Training Grant (HL07557) from the National Institutes of Health.

\section{References}

1. Adibi, S. A., E. L. Morse, and P. M. Amin. 1971. Interrelationships between level of amino acids in plasma and tissues during starvation. Am. J. Physiol. 221:829-838.

2. Adibi, S. A., and D. W. Mercer. 1973. Protein digestion in human intestine as reflected in luminal, mucosal, and plasma amino acid concentrations after meals. J. Clin. Invest. 52:1586-1594.

3. Protein and amino acids. In Recommended Dietary Allowances, Ninth Edition. National Academy of Sciences, Washington, DC. 1980. 39-54.

4. Adibi, S. A. 1980. Roles of branched-chain amino acids in metabolic regulation. J. Lab. Clin. Med. 95:475-484.

5. Adibi, S. A. 1984. Nutritional, physiological and clinical significance of branched-chain amino acids. In Branched Chain Amino and Keto Acids in Health and Disease. S. A. Adibi, W. Fekl, U. Langenbeck, and P. Schauder, editors. S. Karger, Basel. 1-14.

6. Fulks, R. M., J. B. Li, and A. L. Goldberg. 1975. Effect of insulin, glucose, and amino acids on protein turnover in rat diaphragm. J. Biol. Chem. 250:290-298.

7. Buse, M. G., and S. S. Reid. 1975. Leucine: a possible regulator of protein turnover in muscle. J. Clin. Invest. 56:1250-1261.

8. Chua, B., D. L. Siehl, and H. E. Morgan. 1979. Effect of leucine and metabolites of branched-chain amino acids on protein turnover in heart. J. Biol. Chem. 254:8358-8362.

9. Paul, H. S., and S. A. Adibi. 1980. Leucine oxidation and protein turnover in clofibrate-induced muscle protein degradation in rats. J. Clin. Invest. 65:1285-1293.

10. Adibi, S. A. 1971. Alteration in the urinary excretion rate of amino acids and nitrogen by dietary means in obese and normal human subjects. J. Lab. Clin. Med. 77:278-289.

11. Adibi, S. A. 1976. Metabolism of branched-chain amino acids in altered nutrition. Metab. Clin. Exp. 25:1287-1302.

12. Paul, H. S., and S. A. Adibi. 1984. Regulation of branchedchain amino acid catabolism. In Branched Chain Amino and Keto Acids in Health and Disease. S. A. Adibi, W. Fekl, U. Langenbeck, and P. Schauder, editors. S. Karger, Basel. 182-219.

13. Adibi, S. A. 1968. Influence of dietary deprivations on plasma concentration of free amino acids of man. J. Appl. Physiol. 25:52-57.

14. Adibi, S. A., R. T. Stanko, and E. L. Morse. 1982. Modulation of leucine oxidation and turnover by graded amounts of carbohydrate intake in obese subjects. Metab. Clin. Exp. 31:578-588.

15. Matthews, D. E., H. P. Schwarz, R. D. Yang, K. J. Motil, V. R. Young, and D. M. Bier. 1982. Relationship of plasma leucine and $\alpha$-ketoisocaproate during a $L-\left[1-{ }^{13} \mathrm{C}\right]$ leucine infusion in man: a method for measuring human intracellular leucine tracer enrichment. Metab. Clin. Exp. 31:1105-1112.

16. Vazquez, J. A., and S. A. Adibi. 1984. Leucine metabolism during growth and maturity: response to food deprivation. Clin. Res. 32:479A.

17. Rennie, M. J., R. H. T. Edwards, D. Halliday, D. E. Matthews, S. L. Wolman, and D. J. Millward. 1982. Muscle protein synthesis measured by isotope techniques in man: the effects of feeding and fasting. Clin. Sci. 63:519-523.

18. Williamson, D. H., J. Mellanby, and H. A. Krebs. 1962. Enzymic determination of $D-(-) \beta$-hydroxybutyric acid and acetoacetic acid in blood. Biochem. J. 82:90-98.

19. Hutson, S. M., T. C. Cree, and A. E. Harper. 1978. Regulation of leucine and $\alpha$-ketoisocaproate metabolism in skeletal muscle. $J$. Biol. Chem. 253:8126-8133.

20. Dixon, W. J., and F. J. Massey, Jr. 1969. Introduction to Statistical Analysis. Third Edition. McGraw-Hill Book Co., New York.

21. Felig, P., O. E. Owen, J. Wahren, and G. F. Cahill, Jr. 1969. Amino acid metabolism during prolonged starvation. J. Clin. Invest. 48:584-594.

22. Adibi, S. A., and A. L. Drash. 1970. Hormone and amino acid levels in altered nutritional states. J. Lab. Clin. Med. 76:722-732.

23. Paul, H. S., and S. A. Adibi. 1982. Role of ATP in the regulation of branched-chain $\alpha$-keto acid dehydrogenase activity in liver and muscle mitochondria of fed, fasted, and diabetic rats. J. Biol. Chem. 257:4875-4881.

24. Block, K. P., and A. E. Harper. 1984. Valine metabolism in vivo: effects of high dietary levels of leucine and isoleucine. Metab. Clin. Exp. 33:559-566.

25. Hughes, W. A., and A. P. Halestrap. 1981. The regulation of branched-chain 2-oxo acid dehydrogenase of liver, kidney, and heart by phosphorylation. Biochem. J. 196:459-469.

26. Paxton, R., and R. A. Harris. 1984. Regulation of branchedchain $\alpha$-ketoacid dehydrogenase kinase. Arch. Biochem. Biophys. 231: 48-57.

27. Paul, H. S., and S. A. Adibi. 1978. Leucine oxidation in diabetes and starvation: effects of ketone bodies on branched-chain amino acid oxidation in vitro. Metab. Clin. Exp. 27:185-200.

28. Odessey, R., and A. L. Goldberg. 1972. Oxidation of leucine by rat skeletal muscle. Am. J. Physiol. 223:1376-1383. 